along two distinct lines. The first line stems directly from the Physical Science Study Committee's highschool physics course and involves further explorations in the area of curriculum reform in the United States and abroad. An example of this is the Corporation's elementary science programme. The second type of activity undertaken by Educational Services Incorporated is represented by a group such as the National Committee for Fluid Mechanics Films, an autonomous organization operating under the æeis of the Corporation and using its facilities. While funds for the support of such programmes are in most cases granted to the Corporation the groups themselves determine their own policies and operate independently. Educational Services Incorporated has now launched its first Newsletter, which will appear at frequent intervals (1, No. 1; May 1962). It contains accounts of its work on improving curricula as well as a detailed description of the conference held at Accra during December 17-21, 1961, to examine ways in which the teaching of mathematics could be improved and extended. ESI Newsletter is published from 164 Main Street, Watertown, Massachusetts.

\section{Cretaceous Cribrimorph Polyzoa}

THE first monographs devoted to the strikingly beautiful Cretaceous Cribrimorph Polyzoa were published in 1921 and 1922 by Dr. W. D. Lang, who considered that the concept of orthogenesis explained their evolution. His ideas were accepted by some but challenged by others, both at that time and afterwards. In a well-illustrated work, Dr. G. P. Larwood has re-examined the sub-family Pelmatoporinae (The Morphology and Systematics of Some Cretaceous Cribrimorph Polyzoa (Pelmatoporinae), Bull. Brit. Mus. (Nat. Hist.), Geol., 6, No. 1. Pp. 1-285, pls. 1-23. London: Brit. Mus. (Nat. Hist.), 1962). The material dealt with is part of two large collections made by Mr. C. T. A. Gaster, but specimens in other collections, especially that of Mr. R. M. Brydone, were also examined. As a result, Dr. Larwood has reached several conclusions different from Dr. Lang's, notably on the nature of the oral spines, pelmata and pelmatidia, which, in fact, he believes to be the same as the comparable structures in Recent Polyzoa. With the wealth of material available to him, he has also merged a few genera and several species, the ranges of which have thus often been extended. Naturally, the evidence of evolution in the group is affected, and Dr. Larwood concludes that, instead of progressing along confined and determinate, distinct lines, it has taken place in a diverging plexus of variation.

\section{Health Laboratory Services}

ONE of the essential aims of public health in the developing countries should be the co-ordination of all types of laboratories at different levols into a single national health laboratory service that would form an integral part of the national health service. Such a system, in which clinical and public health laboratory activities are closely associated and placed under one technical direction, presents great advantages from the point of view of economy and efficiency. In its third report the World Health Organization Expert Committee on Health Laboratory Services sets out a series of recommendations on the ways and means of achieving this integration, and thus offers guide-lines for developing countries wishing to improve their health laboratory organization. (Technical Report
Series. No. 236: Planning Organization and Administration of a National Health Laboratory Service. Pp. 46. Geneva: World Health Organization; London: H.M.S.O., 1962. 2 Swiss francs; $3 s .6 d . ; 0 \cdot 60$ dollars.) The report opens with a description of the experience of developed countries in establishing a network of health laboratory services, and then defines the scope and functions of such servicesmicrobiological, entomological, hæmatological, pharmaceutical and epidemiological, among others. This is followed by a full account of the many factors involved in the planning, organization and administration of a national health laboratory service in the context of long-term development programmes and in relation to the needs, health problems and resources of the country concerned.

\section{Announcements}

Dr. G. H. Metson, deputy director of research at the Post Office Research Station, Dollis Hill, London, has been awarded the Premium of the Institution of Electrical Engineers (valued at $£ 50$ ) for his papers "The Conductivity of Oxide Cathodes-Part 10: Spontaneous Generation of Negative Ions, and Part 12: Influence of Strontium Ion Migration on Matrix Conductivity", which appeared in the September 1961, and March 1962, issues of the Journal of the Institution of Electrical Engineers.

Tre annual convention of the American Oil Chemists' Society will be held in Toronto during October 1-4. Further information can be obtained from the American Oil Chemists' Society, 35 East Wacker Drive, Chicago 1, Illinois.

A symposrum on "The Rheology of Emulsions", organized by the British Society of Rheology, will be held in Harrogate during October 1-3. Further information can be obtained from Mr. P. E. Knapp. 20 Wayside Avenue, Harrogate.

THE third international symposium on "Batteries" will be held, under the auspices of the Inter-Departmental Committee on Batteries of the British Government, at Bournemouth during October 2-4. Further information can be obtained from Mr. I. B. N. Evans, 30 Fleet Street, London, E.C.4.

THE national conference of the Institute of Personnel Management will be held at Harrogate during October 4-6. The theme of the conference will be "Economic Planning and Incomes Policy". Further information can be obtained from Miss W. A. Kilgour, the Institute of Personnel Management, Management House, 80 Fetter Lane, London, E.C.4.

THE second Thomson Lecture of the Society of Instrument Technology will be delivered by Sir Harry Melville at the Royal Institution, 21 Albemarle Street, London, W.1, on October 4. The title of Sir Harry's lecture will be "The Effect of Instrumental Development on the Progress of Chemistry". Further information can be obtained from the Secretary, the Society of Instrument Technology, 20 Queen Anne Street, London, W.1.

THE twenty-third national conference of the Council for the Preservation of Rural England will be held at Lowestoft during October 4-6. The theme of the conference will be "Post-War Developments in the Countryside". The conference is not confined to members of the Council. Further information can be obtained from the Secretary, the Council for the Preservation of Rural England, 4 Hobart Place, London, S.W.1. 